\title{
Acute Lymphocytic Leukemia in Adults. Pathologic Features and Prognosis
}

\author{
CRISTINA MARINESCU ${ }^{1}$, ANA-MARIA VLADAREANU, FELICIA MIHAI \\ ${ }^{1}$ Department of Hematology, University Emergency Hospital, Bucharest
}

\begin{abstract}
Acute lymphoblastic leukemia (ALL) is a malignant neoplasm of the lymphocyte precursor cells. Among adults it is a relatively rare neoplasm with a curability rate around $30 \%$ at 5 years. Currently, the diagnosis and classification of ALL is a multistep procedure that relies on the simultaneous application of multiple techniques that include: cytomorphology, immunophenotype and cytogenetic assays. Some of which have important clinical implications for both diagnosis and predicting response to specific treatment regimens, while the role of others is still to be defined. Over the years, several prognostic factors have been identified and today a risk stratification at diagnosis and during the follow -up is based on the characteristics of the leukemic cells.
\end{abstract}

Key words: acute lymphoblastic leukaemia, prognostic factors, adults.

Acute lymphoblastic leukemia (ALL) is a heterogeneous hematologic disease characterized by the proliferation of immature lymphoid cells in the bone marrow, peripheral blood or other organs. ALL occurs annually in nearly 4000 people in US [1] and represents $75 \%$ to $80 \%$ of acute leukemias among children, making it the most common form of childhood leukemia; by contrast, ALL represents only about $20 \%$ of all leukemias among adults [2]. ALL is a biologically heterogeneous disorder, so that morphologic, biologic, immunologic, cytogenetic and molecular genetic characterizations of leukemia lymphoblasts are needed to establish the diagnosis or to exclude other possible causes of bone marrow failure and, finally, to classify ALL subtypes. This heterogeneity reflects the fact that leukemia may develop at any point during the multiple stages of normal lymphoid differentiation.

\section{MORPHOLOGY}

Is the main criterion for primary diagnosis of ALL and differentiation from acute myeloid leukemia. The diagnosis of ALL requires demonstration of $>20 \%$ lymphoblasts in bone marrow aspirates and biopsy materials. Three major morphological subtypes, according to the French - American-British (FAB) committee criteria can be distinguished: L1, L2, L3 subtypes (Fig. 1).

Morphologic heterogeneity is almost always seen in L2 and, to a lesser degree, L1 precursor lymphoblasts. Occasional cells with vacuoles can be seen in L2-type precursor lymphoblasts, especially after relapse or therapy. Although the reproductibility of classifying L1 and L2 precursor lymphoblasts is poor, distinguisimg L1 from L2 morphology remains useful for diagnosis and for its descriptive value. L1 is more common in children than in adults $(85 \%$ vs $30 \%)$ and $\mathrm{L} 2$ is more common in adults than in children $(60 \%$ vs $15 \%)$. A prognostic difference between L1 and L2 has never been fully proven, but several studies suggest that patients with the L1 cell type have better response to therapy with better disease-free survival than patients with the L2 cell. Only the L3 (Burkitt) subtype of ALL still holds as a distinct entity characterized by a typical morphology and by its unique immunophenotypic and genotypic features, as well as clinical management and overall outcome. The L3 cell usually has mature B cell characteristics and it is often treated using drugs effective for highly aggressive B cell lymphoma variants (Table I).

\section{CYTOCHEMISTRY}

The key diagnostic cytochemical feature of ALL is the lack of myeloperoxidase (MPO) activity and negativity for nonspecific esterase (NSE). The functional MPO test using cytochemistry remains the gold standard for assessing MPO activity, but laboratories are increasingly the chloroacetate esterase stain, especially for detection by flow cytometry. It is not unusual to detect slightly greater than 3\% MPO-positive blasts in patients with chronic myeloid leukemia in lymphoid blast crisis, with over- 
whelming lymphoid surface markers. Most likely these few MPO-positive blats reflect the active chronic cell population that coexists along with the lymphoid blasts. Sudan black B (SBB) can also be used to confirm the presence of MPO granules in these cells. Periodic acid-Schiff (PAS) staining is also positive in ALL lymphoblasts showing a large, globular pattern. This PAS pattern is not specific and can be seen in other leukemia subtypes. Negativity for MPO and NSE should raise the possibility of an ALL diagnosis, but further flow cytometric evaluation is necessary.

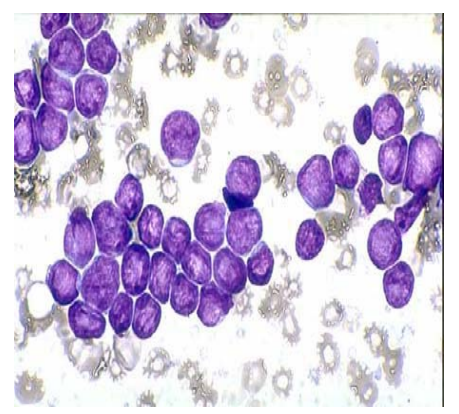

L1 (25-30\%):

small lymphoid cells, homogeneous chromatin, no nucleoli, scanty cytoplasm, regular nuclei Auer rods are never present

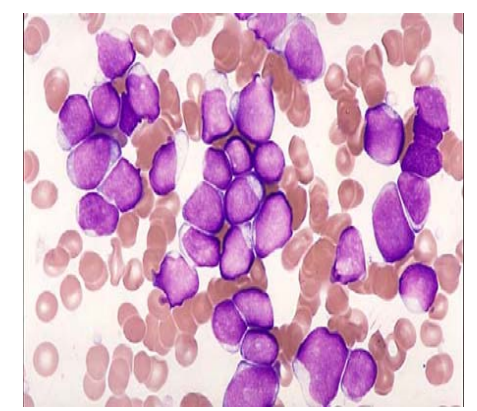

L2 (65-70\%)

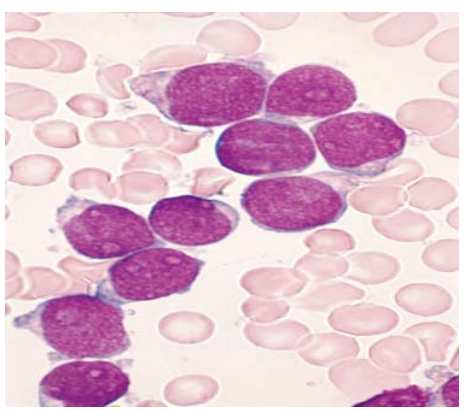

L3 - Burkitt (5-10\%) large heterogeneous cells lacy chromatin irregular nuclear shape, nucleoli present, high nucleus-to -cytoplasm ratio pale basophilic cytoplasm large homogeneous cells, finely stiplled nuclear chromatin prominent nucleolus, strongly basophilic and vacuolated cytoplasm

Figure 1. Cytogenetic abnormalities in pediatric ( $>1$ year) and adult patients with ALL. The majority of children $<1$ year of age carry a rearrangement of the $M L L$-gene and are not included in this graph. Favorable cytogenetic abnormalities are represented in green, neutral in blue, and unfavorable cytogenetics are represented in yellow/red. Favorable cytogenetics (high hyperdiploidy, ETV6-RUNX1) decrease, while the frequency of $B C R / A B L 1$ rearrangement increases with age. The higher percentage of unfavorable cytogenetics substantially contributes to inferior outcomes in adult versus pediatric ALL.

Table I

Immunophenotypic EGIL classification

\begin{tabular}{|c|c|}
\hline B-cell lineage & T-cell lineage \\
\hline $\begin{array}{l}\text { B-I (pro-B) ALL } \\
\text { TdT +, CD19 / CD } 22 / \mathrm{CD} 79 \mathrm{a}+ \\
\text { CD } 10-, \text { c } \mu-, \operatorname{sIg}-\end{array}$ & $\begin{array}{l}\text { T-I (pro-T) ALLpro - T } \\
\text { TdT }+ \text {, cy CD } 3+, \mathrm{CD} 7+\end{array}$ \\
\hline $\begin{array}{l}\text { B-II (common) ALL } \\
\text { TdT }+, \text { CD19/ CD } 22 / \text { CD 79a }+ \\
\text { CD } 10+(\text { CALLA }), c \mu-, \text { sIg - , cy Ig - }\end{array}$ & $\begin{array}{l}\text { T-II (pre-T) ALL } \\
\quad \text { TdT }+, \text { CD } 2+\text { si / sau CD 5+ }\end{array}$ \\
\hline $\begin{array}{l}\text { B-III ( pre - B) ALL } \\
\text { TdT }+, \text { CD } 19 / \text { CD } 22 / \text { CD 79a }+ \\
\text { CD } 10+, \text { c } \mu+, \text { sIg - , cy Ig }+\end{array}$ & $\begin{array}{l}\text { T-III (cortical) ALL } \\
\text { TdT }+, \text { cy CD } 3+, \text { CD } 2 / 5 / 7+ \\
\text { CD } 1 \mathrm{a}+, \text { CD } 4+/ \mathrm{CD} 8+\end{array}$ \\
\hline $\begin{array}{l}\text { B-IV (mature) ALL } \\
\text { TdT -, CD19/ CD } 22 / \text { CD 79a }+ \\
\text { CD } 10+, \text { sIg }+, \text { cy Ig }+\end{array}$ & $\begin{array}{l}\text { T-IV (mature) ALL T } \\
\text { TdT }+/-, \text {, CD } 3+, \text { CD } 2 / 5 / 7+ \\
\text { CD } 1 \mathrm{a}-, \text { CD } 4+\text { sau CD } 8+\end{array}$ \\
\hline
\end{tabular}

\section{IMMUNOPHENOTYPING}

Leukemia cells in ALL are classified according to immunophenotype using an extensive panel of monoclonal antibodies to cell surface "cluster of differentiation" (CD) markers. The scoring system proposed by EGIL group addressed the characterization of the acute leukemia as B or T-lineage ALL by including the most specific markers for the lymphoid lineages among those of earlier stages of cells differentiation plus some non-specific but stem-cell markers. The system introduced a modified terminology specific to each "maturation" step within the B or T-cell lineage and was confirmed of ALL adequate for both diagnosis and subclassification of ALL.

Historically, immunophenotype has been considered as one of the most important prognostic 
factors and has had a major impact on the therapeutic strategy. A decade ago, almost all studies reported this to be of independent significance, with T-lineage ALL having a higher initial response rate as well as a superior long-term survival (Fig. 2).

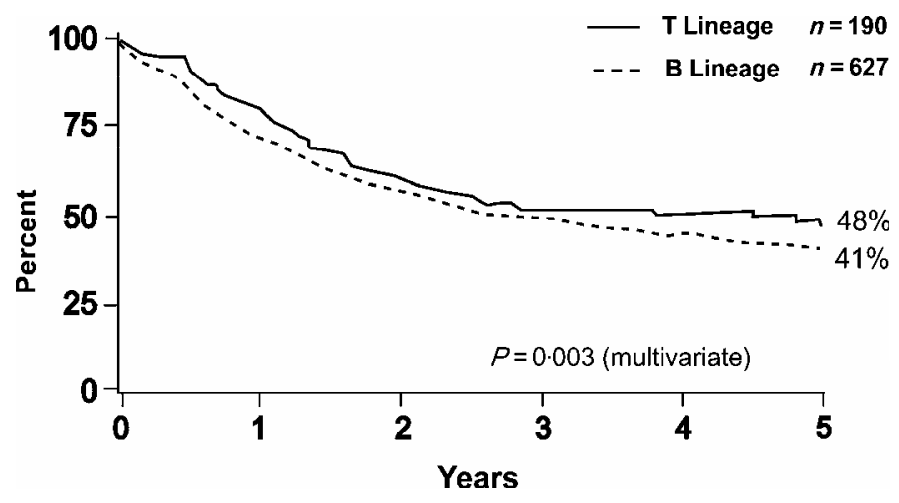

Figure 2. Overall survival by immunophenotype. MRC UKALLXII / ECOG 2993 trial [4].

Similarly, the pro-B and the immature T-cell precursor are generally associated with a worse prognosis.CD34 is the most commonly used antigen to define immature hematopoietic progenitor cells. About $70 \%$ of ALL cases are CD34+. The incidence of $\mathrm{CD} 34$ expression is more frequent in B-lineage ALL (70-80\%) than in T-lineage ALL (20-30\%); its expression has been recorded in a high proportion of $\mathrm{Ph}+\mathrm{ALL}$. Most cases of B-ALL and T-ALL also show expression of one or several myeloid-associated antigens, often CD13 and CD33 and less often CD11b, CD15, and CD66c and rare case CD117. The expression of myeloid antigens by ALL cells seems to confer a worse prognosis, partly because of an association with other major adverse prognostic factors (like $\mathrm{Ph}$ chromosome). CD20 expression in B-lineage ALL has been reported to be associated with poor prognosis for long-term relapse, even though the initial remission rate may be unaffected and preliminary data on therapy with rituximab appear to be encouraging. Although most of the data have been described in childhood ALL, there has also been a recent report of the use of rituximab in adults with ALL [5]. In fact, in a more recent study immunophenotype was not found to be an independently significant prognostic factor. It is likely in the future that cytogenetic and molecular classifications will also supersede immunophenotype as a critical diagnostic tool. Nevertheless, immunophenotyping is likely to remain of major importance in selecting therapies due to the development of specific or targeted approaches directed against the antigenic determinants in B- or T-lineage ALL.

\section{CYTOGENETICS - MOLECULAR ABNORMALITIES}

The identification of cytogenetic and molecular abnormalities provides prognostic information, markers for therapy and targets for drug development and pathobiologic insights. Cytogenetic analysis and molecular cytogenetic studies, such as fluorescence in situ hybridization (FISH), reveal recurring chromosome abnormalities in approximately $80 \%$ of ALL, including numerical and structural changes, such as translocations, inversions or deletions [6]. There are substantial differences between children and adults with ALL in the frequencies of some recurring abnormalities (Table II).

Table II

Cytogenetics of known prognostic significance in adult ALL [5]

\begin{tabular}{|ll|}
\hline $\mathrm{t}(9 ; 22)(\mathrm{q} 34 ; \mathrm{q} 11)$ & \\
$\mathrm{t}(4 ; 11)(\mathrm{q} 21 ; \mathrm{q} 23)$ & Poor prognosis \\
$\mathrm{t}(8 ; 14)(\mathrm{q} 24.1 ; \mathrm{q} 32)$ & \\
Low hypodiploidy/near triploidy & \\
Complex karyotype & Conflicting data \\
\hline $\mathrm{t}(1 ; 19)(\mathrm{q} 21 ; \mathrm{p} 13.3)$ & Better prognosis \\
\hline $\begin{array}{l}\text { High hyperdiploidy } \\
\text { Del (9q) }\end{array}$ \\
\hline
\end{tabular}


The $\mathrm{t}(9 ; 22)$ (q34; q11) resulting in the Philadelphia $(\mathrm{Ph})$ chromosome is the most frequent rearrangement in adult ALL. The fusion product of the $\mathrm{Ph}$ chromosome is the BCR-ABL1 protein with tyrosine kinase activity. The $\mathrm{Ph}$ chromosome is the genetic hallmark of chronic myeloid leukemia. The frequency of BCR-ABL1 rearrangement in ALL increases with age [7]: is observed in about $5 \%$ of children compared with about $30 \%$ of adults and has been reported as high as $50 \%$ in the elderly. Since the discovery of the tyrosine kinase inhibitors (TKI), new options in the treatment of $\mathrm{Ph}+$ leukemia have been embraced but, despite advances in conventional chemotherapy and targeted therapy, $\mathrm{Ph}^{+}$ALL continued to be a very poor prognostic variable in adult and pediatric ALL.

About $15-20 \%$ of ALL harbor a gene expression profile similar to that of $\mathrm{Ph}+\mathrm{ALL}$ without the BCR-ABL1 translocation. This identifies a genetically distinct subgroup of ALL, called "BCR-ABL1-like ALL". Preclinical studies have shown that these leukemic cells are sensitive to inhibition with TKI, suggesting that these patients could be successfully treated with TKI [8].

JAK mutations are present in up to $35 \%$ of Down syndrome-associated ALL and in about $10 \%$ of Philadelphia chromosome-positive $(\mathrm{Ph}+)$, high risk pediatric ALL and have been associated with poor outcomes. In adults, JAK1 mutations were more prevalent in T cell precursor ALL, where they account for $18 \%$ of cases. Mutations of JAK in adults were associated with a poor response to therapy [9]. These fusions responded remarkably well to the JAK inhibitor ruxolitinib (approved from FDA for the treatment of myelofibrosis) [10].

Cytogenetic analysis of each patient's ALL cells has become an essential component of diagnosis prior to treatment. Specific and wellcharacterized recurring chromosomal abnormalities facilitate diagnosis, confirm subtype classification and have major prognostic value for treatment planning. The detection of leukemia-associated clonal genetic changes at the karyotypic and genetic levels has been extensively tested by molecular biology techniques, based on reverse-transcriptase polymerase chain reaction (RT-PCR). In molecular terms, chromosomal abnormalities or their submicroscopic equivalents are two general types : those in which the breakpoint occurs within the involved genes, leading to the production of a fusion RNA transcript and a chimeric protein (qualitative change) and those which represent Ig/TCR rearrangement errors (quantitative change). Qualitative abnormalities are found to produce functional fusion genes: the most common events in B-lineage ALL include: $-\mathrm{t}(9 ; 22)(\mathrm{q} 34 ; \mathrm{q} 11)$ which forms the BCRABL fusion gene;

- $\mathrm{t}(1 ; 19)$ (q23; p13), where the E2A gene fuses with PBX1 and

$-\mathrm{t}(4 ; 11)(\mathrm{q} 21 ; \mathrm{q} 23)$ which involves the MLL gene.

Qualitative fusion transcripts predominate in B-lineage ALL and recombinate errors are rare; in contrast, they are much more frequent in T-ALL, where they represent the majority of molecular abnormalities.

\section{MINIMAL RESIDUAL DISEASE}

Although response rate is an important factor in predicting prognosis, improved methods of assessing treatment response are desirable. Most bone marrow aspirates performed at the end of induction therapy show histologic evidence of "complete" remission (CR), defined as less than $5 \%$ lymphoblasts in a bone marrow with evidence of hematopoietic recovery. Many patients in clinical CR, however, continue to have a small number of leukemic lymphoblasts in their bone marrow. The presence of such 'minimal residual disease' (MRD) can be detected by flow cytometry or polymerase chain reaction (PCR) at various points in the treatment course. Prospective MRD monitoring studies confirm that the probability of long-term, relapse-free survival is directly related to the level of residual disease, both early in the course of treatment and at later time points.

\section{PROGNOSTIC MODELS IN ACUTE LYMPHOBLASTIC LYMPHOMA}

The prognosis of ALL has improved dramatically over the past several decades as a result of adapting therapy to the level of risk for relapse, improvements in supportive care, and optimization of the existing chemotherapy drugs. Over the past decades, there has been a considerable improvement in the outcome of children, with complete remission reaching 95\% and long-term survival rates reaching $80 \%$. In contrast to childhood ALL, therapy of adults with ALL remains unsatisfactory. The long-term survival rate for adults has not significantly changed during the past 2 decades with a 5 -year overall survival of only $30-40 \%$ for patients younger than 60 years , less than $15 \%$ for patients older than 60 years and less 5\% for patients older than 70 years [11]. Diagnostic and clinical features at presentation can 
be combined to identify discrete risk groups. In adult, the most important risk factors are age, white blood cell (WBC) count, a pro-B ALL and poor prognosis molecular markers [12]. Early prospective multicenter studies demonstrated that older age ( $>35$ years) and higher initial WBC count were significantly predictive of decreased reemission duration. While the International Childhood Acute Lymphoblastic Leukaemia Workshop has recommended four categories for prognostic risk assessment in childhood ALL, most adult ALL patients are classified into standard risk and high risk. The guidelines stratify adult patients in high risk when having any of the following poor-risk factors: elevated WBC ( $\geq 30 \times 10^{9} / \mathrm{L}$ for B-cell lineage; $\geq$ $100 \times 10^{9} / \mathrm{L}$ for T-cell lineage); hypodiploidy; MLL rearrangements. That data demonstrating the effect of WBC are less firmly established than for pediatric population. The absence all of the above poor-risk factors is considered standard risk. But cytogenetics and molecular features have moved to the forefront of prognostic classification in ALL, providing not only significant prognostic information, but also specific therapies and allowing for the development of targeted drug therapy. The use of MRD may be the most discriminatory prognostic assessment to make the difficult decisions on which patients ought to receive an allogeneic transplant and in which patients this procedure may be spared. Prognostic factors based on response to therapy, such as the assessment of MRD, have formed a cornerstone of current and future practice.

The evolving paradigm of prognostic factors for ALL in adults [5] (Table III).

Table III

The evolving paradigm of prognostic factors for ALL in adults [5]

Age
Morphology-cytochemistry
Immunophenotyping
a) For prognosis
b) For MRD determination
c) For targeted therapy
Cytogenetics CNS disease
Ph chromosome
Other
Molecular and genetic markers
Gene-expression microarrays
Minimal residual disease

\section{CONCLUSION}

Acute lymphoblastic leukemia (ALL) remains one of the most challenging adult malignancies with varied and complex features at presentation. Remarkable progress has been made in the treatment and outcome over the past 3 decades. This progress is the result of an accumulation of a mosaic of knowledge and experience. Immunophenotyping, cytogenetic-molecular studies, and, more recently, high-resolution genome-wide screening are characterizing ALL as a heterogeneous disease with distinct manifestations and prognostic and therapeutic implications.

Leucemia acută limfoblastică (ALL) este o neoplazie malignă a celulelor precursoare limfoide. În rândul adulților, este o neoplazie relativ rară cu o rată de curabilitate la 5 ani în jur de 30\%. Actualmente, diagnosticul şi clasificarea ALL este o procedură ce presupune mai multe etape care se bazează pe aplicarea simultană de tehnici multiple ce includ: examinări citomorfologice, imunofenotipice şi citogenetice. Unele dintre ele au o implicare clinică importantă 
atât în diagnostic cât şi în estimarea răspunsului la regimurile de tratament specific, în timp ce rolul celorlalte rămâne să fie definit. De-alungul anilor, au fost identificați anumiți factori de risc, iar astăzi, caracterizarea celulei leucemice stă la baza stratificării riscului la diagnostic şi în timpul evoluției bolii.

Corresponding author:

\section{REFERENCES}

1. JEMAL A, SIEGEL R, WARD E, MURRAY T, XU J, SMIGAL C, et al. Cancer statics, 2006, CA Cancer J Clin, 56:106-130.

2. JABBOUR EJ, FADERL S, KANTARJIAN HM. Adult acute lymphoblastic leukemia. Mayo Clin Proc, 2005, 80:1517-1527.

3. MILLER DR, LEIKIN S, ALBO V, SATHER H, HAMMOND D. Prognostic importance of morphology (FAB classification) in childhood acute lymphoblastic leukemia (ALL). Br J Haematol, 1981, 48:199-206.

4. ROWE JM, BUCK G, BURNETT AK, CHOPRA R, WIERNIK PH, RICHARDS SM, LAZARUS HM, FRANKLIN IM, LITZOW MR, CIOBANU N, PRENTICE HG, DURRANT J, TALLMAN MS \& GOLDSTONE AH. Induction therapy for adults with acute lymphoblastic leukaemia: results of more than 1500 patients from the international ALL trial: MRC UKALL XII/ECOG E2993. Blood. 2005; 106, 3760-3767.

5. JACOB M ROWE. Prognostic factors in adult acute lymphoblastic leukaemia. British Journal of Haematology, 2010, 150, 389-405.

6. MOORMAN AV, CHILTON L, WILKINSON J, et al. A population-based cytogenetic study of adults with acute lymphoblastic leukemia. Blood, 2010; 115:206.

7. MROZEK K, HARPER DP, APLAN PD. Cytogenetics and molecular genetics of acute lymphoblastic leukemia. Hematol Oncol Clin North Am, 2009, 23(5):991-1010.

8. KENDERIAN S, LITZOW M. Clinical oncology in adolescents and young adult. 2013: 3 49-62.

9. FLEX E, PETRANGELI V, STELLA L, et al. Somatically acquired JAK1 mutations in adult acute lymphoblastic leukemia. J Exp Med, 2008, 205 (4):751-758.

10. ROBERTS K. Genetic profile in ALL - should all patients be screened? American Society of Hematology (ASH), $53^{\text {rd }}$ Annual Meeting: Abstract 67. Presented December 12, 2011.

11. FIELDING AK, RICHARDS SM, CHOPRA R, et al. Outcome of 609 adults after relapse of acute lymphoblastic leukemia (ALL); an MRC UKALL 12/ECOG 2993 study. Blood, 2007; 109: 944-950.

12. BASSAN R, HOELZER D. Modern therapy of acute lymphoblastic leukemia. J Clin Oncol, 2011; 29(5):532-43.

Received February 12, 2015 